Armando P. Delfino, 2019

Volume 5 Issue 2, pp. 123-140

Date of Publication: 05th August 2019

DOI-https://dx.doi.org/10.20319/pijss.2019.52.123140

This paper can be cited as: Delfino, A. P., (2019). Spiritual Leadership and Job Satisfaction of Teaching and Non-Teaching Personnel of Partido State University. PEOPLE: International Journal of Social Sciences, 5(2), 123-140.

This work is licensed under the Creative Commons Attribution-Non Commercial 4.0 International License. To view a copy of this license, visit http://creativecommons.org/licenses/by-nc/4.0/ or send a letter to Creative Commons, PO Box 1866, Mountain View, CA 94042, USA.

\title{
SPIRITUAL LEADERSHIP AND JOB SATISFACTION OF TEACHING AND NON-TEACHING PERSONNEL OF PARTIDO STATE UNIVERSITY
}

\author{
Armando P. Delfino \\ Partido State University, Goa, Philippines \\ ardel1975@gmail.com
}

\begin{abstract}
School leadership is tasked to help faculty developed their potentials so that they could contribute to the attainment of the objectives of the university. Failure of the leadership to inspire its people would result to low performance of the institution. This study analyzed the correlation between spiritual leadership and job satisfaction of the teaching and non-teaching personnel of Partido State University.The study used descriptive-correlational research design to describe the relationship between spiritual leadership and job satisfaction. The Data were treated through Statistical Package for Social Sciences (SPSS). Focused Group Discussion (FGD) was used to verify and gather additional data from the respondents. The researchers used standardized questionnaires on Spiritual Leadership and Job Satisfaction. The respondents of the study were the 81 faculty members and 63 non-teaching personnel of Partido State University. Findings of the study revealed that the extent of spiritual leadership in Partido State University was high and the job satisfaction was slightly satisfying. The results of the t-test revealed that among the seven dimensions of Spiritual Leadership altruistic love and productivity were found to be significantly different between the teaching and the non-teaching personnel. Furthermore, Spiritual Leadership was found to have a weak correlation to job satisfaction of the teaching and non-teaching personnel of Partido State University. The university officials should continue reaching out to its
\end{abstract}


employees and communicate clearly the directions of the institution. Furthermore, the fair and just working environment should be strengthened so that, it would be felt by all employees. Enough support should be given to all employees based on their needs to increase their productivity. Spiritual leadership should be strengthened to promote healthy working environment and increase job satisfaction among employees.

\section{Keywords}

Spiritual Leadership, Job Satisfaction, Faculty, Non-Teaching Personnel, Partido State University

\section{Introduction}

Partido State University is the premier university in Partido Area. As a premier university in the district, it needs to respond to the challenges of providing quality education to the students, conducting research geared toward the development of the potentials of the district and partnering with the government in delivering services to the people by through its community and extension services.

The burden of fulfilling these tasks rests to the manpower of the university, most, especially the teachers. This vital role necessitates them to be academically prepared to fulfill such important jobs. However, academic preparation is not an assurance that the teachers would successfully fulfill their duties. To become truly productive, their needs should also be given attention. As Ken Blanchard puts it: if you want people to be responsible, be responsible to their needs. No matter how academically prepared they are, they are bound to fail and underperformed if they could not find satisfaction in their working environment. There are many well-qualified faculty members who resigned from their present jobs and transferred to other institutions due to the prevailing unsatisfying working conditions and leadership issues surrounding their universities. Some are receiving a pretty good pay, but their take home pay did not prohibit them to leave. Salary is not a guarantee that the workers would stay in their jobs. As Milliman, John et al. (2018), revealed workplace spirituality has a direct effect on employee engagement and intention to stay in their works. Saari and Judge (2004), happy employees are productive employees. It was also said that teachers who are satisfied with their jobs are teachers who will likely work efficiently and stay in the profession. (Bustamante and Delfino, 2013)

The task of helping the teacher, and the workforces of the university lies in the hands of its leader. Leadership energizes the whole organization to become productive, efficient, and dynamic. It turns the university into a very productive organization. A very productive 
organization is one where all its stakeholders perform, contribute, and collaborative harmoniously so as to accomplish the goals of the schools. Bringing the workers to work together and setting aside personal and professional jealousies is a gargantuan task a leader must face. It is a great challenge that many of the leaders failed to do. Surpassing this challenge would need a leadership paradigm that addresses the aspect that defines the essence of human existence. It requires a leadership that transforms potential into reality and undertands its people as humans who also need nourishment. Spiritual leadership is a new leadership paradigm believed to promote productivity among workers through a unique approach. Spirituality at work is about understanding each other's needs, looking for a sense of connectedness, and finding meaning and purpose for existence. Walt, (2018) added that spiritual workplaces need to be created to promote work engagement and thriving at work. Spiritual leaders ensure others feel engaged, foster integrity, promote a sense of connection and community, are sensitive to stakeholders, and foster unity in a culturally diverse work force (Fairholm, 2000). Honesty, integrity, and humility are values that are requisites for spiritual leaders. Furthermore, they should have a vision for the organization and must be able to inspire their people.

Spirituality at work is an inspiring and motivating force for constantly searching for meaning and purpose in the work life, personal understanding of the value of work and personal belief system. Spirituality should be seen as an integral characteristic of leaders in today's organizations. This inseparability is a factor, which contributes towards self- development so as to achieve higher levels of internal and external work success (Aydin and Ceylan, 2008).

Many researches had been done and showed the positive effects of spiritual leadership to job satisfaction. Nonetheless, studies about it in the state colleges and universities in the Philippines have not been conducted. As revealed in the study of Saner and Eyupoglu, (2009), job satisfaction has significant implications between the faculty and the administration of higher educational organizations. It was corroborated by the study of Syed et al., (2012), where they found that the faculty's job satisfaction is the most significant aspect in higher education and is important for the improvement, efficacy, and effectiveness of the higher education system.

This study aimed to determine the extent of spiritual leadership and job satisfaction of teaching and non-teaching personnel of Partido State University. Specifically, it determines the differences of spiritual leadership among the groups of respondents and the correlation between spiritual leadership and job satisfaction. 


\section{Literature Review}

Spiritual leadership is a kind of leadership that utilizes values and sense of calling and membership to motivate followers (Northouse, 2016). The sources and the factors for the development of the spiritual leadership of the school heads were spiritual meanings and programs, past experiences, family influence, beliefs, and college lives (Banke, Maldonado, and lacey, 2012). For organizations to implement spiritual leadership, they must co-create a vision wherein both leaders and followers experience a sense of calling that their life has a meaning and makes a difference; put into effect an organizational culture based on the values of altruistic love; and support employees' inner life, spiritual, or mindful practices to help them be more self-aware and conscious (Fry and Nisieiwcz, 2013).

There have been studies conducted that showed the positive impact of spiritual leadership to the job satisfaction of the workers of different organizations in different countries. In the study of Hassan, Misbah et al. (2016), it was found out that there was a positive relationship between workplace spirituality and job satisfaction. Similarly, Yusof (2011) discovered that some dimensions of spiritual leadership such as membership, meaning, altruistic love, vision, and hope/faith were found to be associated with job satisfaction. Osboei and Nojabaee (2016) found $34 \%$ variations of correlation between spiritual leadership and quality of working life. Furthermore, it was discovered that the quality of the working life among education employees was much affected by faith/hope.

In addition Gupta, M. et al. (2013), Hassan, Misbah, et al. (2016), and Mahipalan, (2018), found a positive link among the dimensions of spirituality in the workplace and job satisfaction and organizational engagement. The new leadership paradigm does not only affect job satisfaction but other aspects of work lives too. As Swanepoel (2015) and Pio (2017), affirmed the positive roles of spirituality in the quality of work life, job satisfaction and job involvement. Monu Lal Sharma, Akbar Hussain (2012), also reported a positive relationship between the scores of workplace spirituality and employee engagement. Panes et al. (2017) added that spiritual leadership and school culture were drivers of job satisfaction of the teaching force. Furthermore, Musta'in, Mudjib and Abdul Manan, (2014), revealed that the implementation of a spiritual leadership model enhanced the work motivation and strengthened employees' satisfaction in improving a work performance at University Darul Ulum.

The benefits of spiritual leadership go beyond job satisfaction, as it was associated high workers' commitment (Ahiauzu, 2009) and decrease job stress, (Yaghoubi et al., 2010). It was also 
observed that the peace and performance oriented behaviors of primary school principals enabled the teachers to perceive positively the administrative efforts, (Karadag, 2009). It could further be used to preserve Catholic values, and the vision of service (Dayler and Fry, 2012) and improve the level of engagement of employees (Devedhiran and Wesley, 2017).

\section{Methodology}

\subsection{Design}

The study used the descriptive-correlational research design to describe the spiritual leadership of PSU and job satisfaction of the teaching and non-teaching personnel and look for the correlations between the two. It looks at the relationships between and among two or more variables.

\subsection{Respondents}

The researcher used a purposive sampling technique through total enumeration of respondents. The respondents of the study were the permanent faculty members and non-teaching personnel (permanent and casual) who have served University for at least one year. A total of 83 faculty members from four colleges (Education, Arts and Sciences, Engineering, and Business Education) and 61 non-teaching personnel in the main campus of Partido State University participated in the study.

\subsection{Instrument}

The researchers used standardized questionnaires on Spiritual Leadership and Job Satisfaction. The Spiritual Leadership was the work of Dr. Louis Fry of A and M University in Texas, United States of America while the job satisfaction questionnaire was adapted from the work of Delfino and Bustamante (2013).

\subsection{Procedure}

The researcher sought the permission of the university presidents before the questionnaires were distributed to the faculty and non-teaching personnel of the university. The researcher personally supervised the distribution and retrieval of the questionnaires from the respondents. Focused group discussion was conducted to obtain additional information from the respondents, which were not captured by the questionnaires.

\subsection{Data Analysis}

The gathered data were treated using Statistical Package for Social Sciences (SPSS). Specifically the following statistical tools were used: Mean and ranking to determine the extent of 
the spiritual leadership and job satisfaction of teaching and non-teaching personnel of Partido State University; t-test to determine if there were significant differences in spiritual leadership between the faculty and non-teaching personnel; and Pearson's Correlation Coefficient to determine if there is a significant relationship between spiritual leadership and organizational performance.

\section{Results and Analysis}

Table 1: Extent of Spiritual Leadership in Partido State University

\begin{tabular}{|l|c|c|c|}
\hline Dimensions of Spiritual Leadership & Mean & QI & \multicolumn{2}{|c|}{ Rank } \\
\hline 1. Meaning/Calling & 3.40 & Very High & $1^{\text {st }}$ \\
\hline 2. Faith/Hope & 3.27 & High & $2^{\text {nd }}$ \\
\hline 3. Productivity & 3.26 & High & $3^{\text {rd }}$ \\
\hline 4. Vision & 3.15 & High & $4^{\text {th }}$ \\
\hline 5. Membership & 2.98 & High & $5^{\text {th }}$ \\
\hline 6. Organizational Commitment & 2.95 & High & $6^{\text {th }}$ \\
\hline 7. Altruistic Love & 2.85 & High & $7^{\text {th }}$ \\
\hline Average & $\mathbf{3 . 1 2}$ & High & \\
\hline
\end{tabular}

Legend: 1.00-1.70 - Very Low 1.80-2.50 - Low

2.60-3.30-High 3.40-4:00 - Very High

Table 1 shows that the level of spiritual leadership in Partido State University was high $(\mathrm{M}=3.12)$. Meaning/calling was rated very high $(\mathrm{M}=3.40)$, faith/hope was second with a mean of 3.27 (high), productivity was third with a mean of 3.26 (high), vision was fourth with a mean of 3.15 (high), membership was fifth with a mean of 2.98 , organizational commitment was sixth with a mean of 2.95 (high), and altruistic love has the lowest mean of 2.85 (high).

Table 2: Differences in Spiritual Leadership between Teaching and Non-Teaching Personnel of PSU

\begin{tabular}{|l|c|c|c|c|c|}
\hline \multirow{2}{*}{ Group } & \multicolumn{2}{|c|}{ Mean } & \multirow{2}{*}{ Diff } & t \\
\cline { 2 - 5 } & $\begin{array}{c}\text { Teaching } \\
\text { Personnel }\end{array}$ & $\begin{array}{c}\text { Non-teaching } \\
\text { Personnel }\end{array}$ & p value \\
\hline Vision & 3.09 & 3.21 & 0.13 & 1.28 & 0.203 \\
\hline Altruistic Love & 2.73 & 2.99 & 0.26 & $2.47^{*}$ & 0.015 \\
\hline Faith & 3.31 & 3.39 & 0.09 & 1.04 & 0.300 \\
\hline
\end{tabular}




\begin{tabular}{|l|c|c|c|c|c|}
\hline Meaning & 3.37 & 3.37 & 0.00 & 0.01 & 0.992 \\
\hline Membership & 2.90 & 3.05 & 0.15 & 1.41 & 0.160 \\
\hline Productivity & 3.10 & 3.41 & 0.30 & $3.31^{*}$ & 0.001 \\
\hline OrganizationalCommitments & 2.93 & 3.02 & 0.08 & 0.90 & 0.368 \\
\hline
\end{tabular}

* significant at 0.05 level of significance

Table 2 shows that altruistic love and productivity between teaching and non-teaching were significantly different at $5 \%$ significance level. On the other hand, table 2 further showed that there were no significant differences among vision, faith, meaning, membership, and organizational commitment of teaching and non-teaching personnel of Partido State University.

Table 3: Job Satisfaction of PSU Teaching and Non-teaching Personnel

\begin{tabular}{|l|c|c|c|}
\hline \multicolumn{1}{|c|}{ Indicators } & Mean & QI & Rank \\
\hline 1. Achievement & 3.23 & Slightly Satisfying & $1^{\text {st }}$ \\
\hline 2. Status & 3.21 & Slightly Satisfying & $2^{\text {nd }}$ \\
\hline 3. Interpersonal Relationship & 3.14 & Slightly Satisfying & $3^{\text {rd }}$ \\
\hline 4. Responsibility & 3.08 & Slightly Satisfying & $4^{\text {th }}$ \\
\hline 5. Supervision & 3.05 & Slightly Satisfying & $5^{\text {th }}$ \\
\hline 6. Recognition & 3.03 & Slightly Satisfying & $6^{\text {th }}$ \\
\hline 7. Working Condition & 3.00 & Slightly Satisfying & $7^{\text {th }}$ \\
\hline 8. Possibility of Growth and Advancement & 3.00 & Slightly Satisfying & $7^{\text {th }}$ \\
\hline \multicolumn{1}{|c|}{ Average } & $\mathbf{3 . 0 9}$ & Slightly Satisfying & \\
\hline
\end{tabular}

Legend: 1.00-1.75: Highly Dissatisfying, 1.76-2.50: Slightly Dissatisfying, 2.51-3.25: Slightly Satisfying,

3.26-4.00: Highly Satisfying

Table 3 shows that the job satisfaction of the teaching and non-teaching personnel of Partido State University was slightly satisfying $(M=3.09)$. Achievement has the highest mean of 3.23 (slightly satisfying), status was second with a mean of 3.21 (slightly satisfying), interpersonal relationship was third with a mean of 3.14 (slightly satisfying), responsibility was fourth with a mean of 3.08, supervision was fifth with a mean of 3.05 (slightly satisfying), recognition was sixth with a mean of 3.03 (slightly satisfying), and working condition and possibility growth and of advancement had the lowest mean of 3.00 (slightly satisfying). 
Table 4: Correlation between Spiritual Leadership and Job Satisfaction of PSU Teaching and Non-Teaching Personnel

\begin{tabular}{|l|c|c|c|}
\hline \multicolumn{1}{|c|}{$\begin{array}{c}\text { Dimensions of Spiritual } \\
\text { Leadership }\end{array}$} & $\mathbf{r}_{\mathrm{xy}}$ & Strength of Correlation & p value \\
\hline Vision & $0.197^{*}$ & weak & 0.017 \\
\hline Altruistic Love & $0.231^{*}$ & weak & 0.005 \\
\hline Faith & $0.163^{*}$ & weak & 0.049 \\
\hline Meaning & 0.123 & weak & 0.138 \\
\hline Membership & $0.208^{*}$ & weak & 0.011 \\
\hline Productivity & $0.216^{*}$ & weak & 0.009 \\
\hline Organizational Commitments & $0.241^{*}$ & weak & 0.003 \\
\hline $\begin{array}{l}\text { Spiritual Leadership and Job } \\
\text { Satisfaction }\end{array}$ & $0.235^{*}$ & weak & 0.004 \\
\hline
\end{tabular}

* significant at 0.05 level of significance (two-tailed)

Table 4 shows that the six dimensions of spiritual leadership such as vision $(\mathrm{p}=0.017)$, altruistic love $(\mathrm{p}=0.005)$, faith $(\mathrm{p}=0.049)$, membership $(\mathrm{p}=0.011)$, productivity $(\mathrm{p}=0.009)$, and organizational commitments $(0.003)$ were found out to have positive direct correlation to the job satisfaction of the teaching and non-teaching of Partido State University at 5\% significance level.

Overall there was a significant weak positive correlation noted between the spiritual leadership $(\mathrm{M}=3.11, \mathrm{SD}=0.49)$ and job satisfaction $(\mathrm{M}=3.08, \mathrm{SD}=0.49), \mathrm{r}=.235, \mathrm{p}=.004, \mathrm{~N}=147$, with $5 \%$ of the variance being explained by the linear relationship between the variables.

\section{Discussion and Conclusions}

\subsection{Spiritual Leadership}

The study revealed that the Partido State University community rated high the spiritual leadership exhibited by its officials. Meaning/calling has the highest mean (3.40) while altruistic love has the lowest mean (2.85). The result was similar to the previous study conducted by Delfino, (2014) where he found meaning/calling as the most important dimension of spiritual leadership while altruistic love as the least important. However, Masouleh et. al (2012) found that altruism is the most important dimension of spiritual leadership, while hope/faith is the least.

Meaning/Calling is a sense that one's life has meaning and makes a difference. The respondents claimed that the works they do were very important and meaningful to them. This is understandable, because their works are their bread and butter. Nevertheless, the importance of 
work does not automatically make it a meaningful one. The work environment and the leadership are vital for its development. Fleishman as cited by Mansor, Ismail, Alwi, and Anwar (2013), suggests that calling is an essential dimension of spiritual survival in the workplace. When work is seen as a calling, rather than, a job or as an opportunity to serve higher power and purpose for the common good, work striving takes on a new significance.

Existential theory of Cohen (2003), explains the connections among calling, religiousness, and career decision making by emphasizing individuals' search for meaning or purpose in life. This theory posits two lenses through which individuals view their lives: Universal and Individual. The universal lens focuses on meaning in all peoples' lives, whereas the individual lens focuses on the meaning within the individual. The main tenet of existential theory is freedom of choice and individuals who choose to view their lives through universal lenses are focused on how their actions affect others, whereas individuals who choose to view their lives through individual lenses are focused on both themselves.

It was also found out that faith/hope has the second highest rating (3.27) among the seven dimensions of Spiritual Leadership. Faith/hope refers to the assurance of things hoped for, the conviction that the organization's vision/purpose/mission will be fulfilled (Fry, L.W., 2003). Accordingly, the respondents strongly displayed faith in the university and its mission by doing what they can do and persevered extra effort to help the university succeed. Faith gives strength to the people to hold on and continue hoping for a brighter future. People with hope/faith possess clarity of where they are going, how to get there, and are willing to face opposition and endurance hardship in order to achieve their goals. He added further that hope/faith is the source of a conviction that the organization's vision, purpose, and mission will be fulfilled. (MacArthur cited by Fry et. al, 2011).

Altruistic love (2.85) and Organizational commitment (2.98) received the lowest rating respectively among the seven dimensions of spiritual leadership. Altruistic love refers to a sense of wholeness, harmony, and well-being produced through care, concern, and appreciation for both self and others. While organizational commitment refers to the degree of loyalty or attachment to the organization (Fry, L. W. 2003).

The respondents take note on the trustworthiness and loyalty of the official to the welfare of the employees. They also highlighted the lack of honesty of some officials of the university. Some faculty members member stressed that they did not feel the care and concern of the administration about their welfare. They felt that the administration was more focused on the 
output and work accomplishment than social and other needs of the faculty members. They even commented that they felt rejection if they could no longer contribute to the university. Furthermore, they underscored that the practice of requiring the faculty members to work beyond the required office hours and even extending in the midnight without thinking about the risk posed to their lives and without any compensation for the additional services was regarded as a lack of concern to their welfare. This practice stole their precious time to their families. Some pinpointed the lack of appreciation by the administration to the senior faculty members who would be retiring and to those who were pillars of the university for without their sacrifices the school would never reach its present status.

Similar results were found in the studies of Delfino (2014) and Malone and Fry (2003) where altruistic love had received a low rating from the respondents. Both studies disclosed personal and leadership issues were haunting faculty members, and the administrations as reasons for such a rating. Delfino (2014), revealed lack of transparency on financial matters and unfair human resource policies on promotions and faculty grants, among others as factors for the lower rating of altruistic love. On the other hand the study of Malone and Fry (2003) leadership and personal issues between the administration and teachers had led to a very intimidating and conflictridden school environment.

Furthermore, some respondents have an apprehension in spending the rest of their career in the university. Most of these respondents were those affected by the requirement of the university to conduct research. Since most of them were high school teachers back then, before the school was converted to college then to university, they complaint of having no enough knowledge to do research. The respondents were willing to conduct research, however, they would like the administration to capacitate them. Some would rather avail of early retirement than continuing service in the university and stressing their lives with the research requirement. Commitment of group's members will be stronger when it is based on human and moral values and also when it has taken place as a result of conscious selection (Kahsefi et al., 2013).

On the other hand, the respondents revealed that they felt like being part of the family and had strong sense of belonging to the university. This could be attributed to the long association among faculty members who have been in the university for a long time. Most of the respondents have been in the university for more than ten years. The time they spent together had developed a strong feeling of closeness and mutual relationship among each other. 
As revealed in table 1, the respondents strongly affirm that they understand and committed to the vision of the university. They added that the vision of the university inspired and brings out the best of them. Vision is the guiding principle for all the members of the university. When the faculty and staff of the university understood it, they will certainly be empowered. Leadership should be credited for making it happened in their organization. The distinguishing characteristics of successful educational leaders are their capacity to provide a vision for the future and inspire hope in those with whom they work. They also lift the spirits of their people and help them translate the vision into the daily practices of their work (Duignan, 2006).

Membership refers to a sense that one is understood and appreciated. The respondents felt that the university demonstrated respect and appreciates their works. They were also valued as a person in their job. These results implied that spiritual leadership in the university had been doing well in valuing the faculty and non-teaching personnel in their work as persons to be respected. The treatments that were shown by the universities to their employees have certainly contributed for the development of their sense of belonging. The acceptability of the faculty and their works in the university simply means that they find common grounds between their personal ideas and a meaningful organizational mission or intention. In this way, the faculty members were able to connect their own identity to that of the organizations and gave them enough reason of caring for the organization where they belong. When leaders recognized employee contributions, employees feel better about the organization, they feel more of a sense of community, and they are more likely to stay with the organization and continue to contribute (Reave, 2005).

Productivity was the third dimension with the highest rating of 3.26. Productivity refers to efficiency in producing results, benefits, or profits. The respondents strongly agreed that everyone is giving the best effort to be productive and that the work quality is a high priority for all workers. This response of the respondents is commendable and should have receive support praise from the administrators. The response is expected because the respondents believe that the work that they do is important and meaningful to them. They were also inspired and committed to the university's vision. If the employees have a positive perception of their work environment, they are inclined them to be more involved in organizational concerns. The productivity of employees brings in the revenues and progress to the organization and as such productivity is affected by the work environment, employment health and wellness, intent and interest in the job, technology, managers, work-life balance, and flexibility (Chakkirala, 2013). 


\subsection{Differences of Spiritual Leadership between Faculty and Non-Teaching Personnel of Partido State University}

As seen in table 2, there were significant differences in spiritual leadership between the teaching and non-teaching personnel of Partido State University in the dimensions of altruistic love and productivity. The data show that in terms of altruistic love non-teaching personnel felt better than the faculty. Specifically, the non-teaching personnel gave a high rating to all the parameters of altruistic love than the faculty. These parameters are the trustworthiness and loyalty to employees, courage, integrity, kindness and being considerate, and honesty.

Productivity for non-teaching personnel was very high as compared to high by the faculty. Specifically, the non-teaching personnel said that everyone in their group gives his/her best work quality is the high priority and they argued that their group is very productive.

The differences could be attributed to the nature and demand of their works. Most of the faculty found it difficult to comply with the academic requirements of the university, most, especially in the area of research and the production of instructional materials. The situation became more complicated by the lack of skills of the faculty members. They interpreted the limited, or the absence of effective trainings of faculty members in the areas of research and the development of instruction negatively. As compared to the non-teaching personnel, demands to the faculty members were a little bit difficult. These could be the reasons for the differences in the two groups of respondents.

\subsection{Job Satisfaction of Faculty and Non-Teaching Personnel}

The respondents described their job satisfaction in terms of achievement, status, interpersonal relationship, responsibility, supervision, recognition, working condition and possibility of growth and advancement as slightly satisfying.

Achievement is one of the motivational factors that could significantly boost the morale of the workers. The respondents were highly satisfied with their performance for being able to complete the assigned tasks given to them. Furthermore, they were able to maintain high standards of teaching and works, and were active in contributing solutions to the problems of the university. The study suggests that the respondents were able to maintain a good performance in relation of their jobs. However, the sustainability and improvement must be given attention by the administration by means of giving them proper rewards. Jex and Britt (2014) said that some employees appreciate and want an acknowledgement for successfully completing a task at work. Others prefer not to receive public praise and are motivated intrinsically. Employees motivated by 
the need for achievement are typically more of the risk takers in the organization. They are also the employees that want to constantly be challenged and learn new things. They described these employees as having a tendency to become very absorbed in their work.

The respondents were slightly satisfied with their status at the university. However, they were highly satisfied with the respect accorded to them by the university and their professional eligibility. They were also slightly satisfied to their participation in the school policy formation. These data conveyed that the morale of the majority of the respondents in the university were in a good spirits. As such, it contributes to the overall satisfaction of the workers in their current jobs.

Interpersonal relationship is another important aspects that can affect the job performance and satisfaction of the workers. Interpersonal relationships among respondents were slightly satisfying. However, working relationship with superiors and students were highly satisfying. It connotes that working with the superiors and students were smooth and good. Nevertheless, the data suggest that the respondents needed the full support of the administration in the area where they could help realized the mission and vision of the university. Furthermore, they expressed the need for an office or person who would handle grievances.

Responsibility is the fourth area with the highest rating and one of the factors that can affect the job satisfaction of the workers. The respondents were slightly satisfied with the responsibility given to them by the university. They were delighted to be encouraged to continually improved themselves, allowed to make important decisions relevant to the job independently, and being helped to spot and correct deficiencies and to do a job the way it should be done.

The respondents were slightly satisfied to the kind of supervision shown by the administration. Specifically, the respondents were happy in the manner the supervision is carried out and on being given the minimum necessary supervision. Furthermore, they were also delighted of the unannounced visits by the superiors and the frequency of the supervision being conducted.

Recognition is another factor that can affect the job satisfaction and performance of the workers. The data showed that the respondents were slightly satisfied to the kind of recognition they received from the administration. Specifically the respondents were satisfied with their standing inside and outside the university, length of service award and being appreciated by peers and students.

The respondents were slightly satisfied to their working conditions. They were specifically happy to the physical plant and site conditions, classroom/office physical conditions and the support services available to them. However, the respondents had a concern to the amount of 
school works and facilities such as library, audio-visual, guidance, infirmary, cafeteria, and faculty workroom. These things received the lowest ratings among the parameters of the work conditions.

Possibility of growth and advancement is one of the biggest considerations a worker looks at when applying for a job. It is a the natural tendency of professional to expect for their growth and advancement since it will give them the chance to be promoted to the higher positions. The faculty and the non-teaching personnel of the university were slightly satisfied in provision of the possibility of growth and advancement. However, they were slightly dissatisfied to the opportunities to work in a supervisory or administrative capacity. It suggests that many of the respondents have interests in handling administrative positions. It could probably mean that the manner and the rules of promotions to the administrative positions need to be reviewed to ensure that it would be fair and transparent.

\section{Conclusion}

The university officials should continue reaching out to its employees and communicate clearly the directions of the university. Furthermore, the fair and just working environment should be strengthened so that, it would be felt by all employees. Enough support should be given to all employees based on their needs to increase their productivity. Social activities that could help lessen the work related stress. Spiritual leadership should be maximized in the university because it is a potential factor that could create a healthy working environment and increased job satisfaction among employees of the University.

\section{References}

Ahiauzu, A. (2009). Altruistic Love Culture and Workers' Commitment in the Nigerian Manufacturing Industry: A Study in Workplace Spirituality. Retrieved from

How do organizational culture and organizational learning capacity jointly affect it? Journal of

Industrial Engineering and Management, 1(2). https://doi.org/10.3926/jiem.2008.v1n2.p143-168

Banke, S., Maldonado, N., \& Lacey, C. H. (2012). Christian School Leaders and

Spirituality. Journal of Research on Christian Education, 21(3), 235-264. https://doi.org/10.1080/10656219.2012.732806

Chakkirala, A. (2013). Top 7 Factors for Enhancing Employee Productivity and Organizational Profitability. Retrieved from www.shrmindia.org 
Cohen, B. N. (2003). Applying Existential Theory and Intervention to Career DecisionMaking. Journal of Career Development, 29(3), 195-209. https://doi.org/10.1177/089484530302900306

Dayler, L. T., \& Fry, L. W. (2012). Impact of Spiritual Leadership on Catholic Organizational Identity. Academy of Management Proceedings, 2012(1), 14202. https://doi.org/10.5465/AMBPP.2012.14202abstract

Delfino, D. P. (2014). Spiritual Leadership and Organizational Performance of Catholic Universities in Bicol Region (Unpublished doctoral dissertation). University of Nueva Caceres, Naga City, Philippines.

Delfino, D. P., Bustamante, M., \& Bustamante, M. P. (2013). Job Satisfaction of Universidad de Start. Isabel Higher Education Department Faculty. Unpublished manuscript, Universidad de Sta. Isabel, Naga City, Philippines.

Devendhiran, S., \& Wesley, J. (2017). Spirituality at work: Enhancing levels of employee engagement. Development and Learning Organization, 31(5), 2017th ser. https://doi.org/10.1108/DLO-08-2016-0070

Duignan, P. (2006). Leadership challenges as tensions. Educational Leadership, 42-62. https://doi.org/10.1017/CBO9781139168564.004

Eyupoglu, S. Z., \& Saner, T. (2009). The relationship between job satisfaction and academic rank: A study of academicians in Northern Cyprus. Procedia - Social and Behavioral Sciences, 1(1), 686-691. https://doi.org/10.1016/j.sbspro.2009.01.120

Fairholm, G. W. (2000). Perspectives on leadership: From the science of management to its spiritual heart. Westport, Conn: Praeger.

Fry, L. W. (2003). Toward a theory of spiritual leadership. The Leadership Quarterly, 14(6), 693727. https://doi.org/10.1016/j.leaqua.2003.09.001

Fry, L. W., \& Slocum, J. W. (2008). Maximizing the Triple Bottom Line through Spiritual Leadership. Organizational Dynamics, 37(1), 86-96. https://doi.org/10.1016/j.orgdyn.2007.11.004

Fry, L. W., \& Nisiewicz, M. S. (2013). Maximizing the triple bottom line through spiritual leadership. Stanford, CA: Stanford Business Books, an imprint Stanford University Press.

Gupta, M., Kumar, V., \& Singh, M. (2013). Creating Satisfied Employees Through Workplace Spirituality: A Study of the Private Insurance Sector in Punjab (India). Journal of Business Ethics, 122(1), 79-88. https://doi.org/10.1007/s10551-013-1756-5 
Hassan, M., \& Ali Bin, A. (2016). Impact of Workplace spirituality on job satisfaction: Mediating Effect of true. Cogent Business and Management. https://doi.org/10.1080/23311975.2016.1189808

Hossam, M., Troung, Q., \& Khalifa, E. (2010). The Relationship between Perceptions of Equity and Job Satisfaction in the Egyptian Private Universities. Eurasian Journal of Business and Economics.

Jex, S. M., \& Britt, T. W. (2014). Organizational psychology: A scientist-practitioner approach. Hoboken, NJ: John Wiley \& Sons.

Karadag, E. (2009). Spiritual Leadership and Organizational Culture: A Case Study of Structural Equation Modeling (32009th ed., Vol. 9). Educational Sciences: Theory and Practice.

Kashefi, M., Adel, R., Abad, H., Aliklayeh, M. H., Moghaddam, H. K., \& Nadimi, G. (2013). Organizational Commitment and Its Effect on Organizational Performance (12th ed., Vol. 4, Ser. 2013). Interdisciplinary Journal of Contemporary Research Business.

Ken Blanchard Quotes. (n.d.). Retrieved from https://www.brainyquote.com/authors/ken_blanchard

Latham, G. P. (2012). Work Motivation: History, theory, research and practice (2nd ed.). Toronto: Sage Publication. https://doi.org/10.4135/9781506335520

Mahipalan, S. S. (2018). Mediating Effect of Engagement on Workplace Spirituality - Job Involvement Relationship: A Study among Generation Y Professionals. https://doi.org/10.1177/2319510X18810995

Malik, M. E., Nawab, S., Naeem, B., \& Danish, R. Q. (2010). Job Satisfaction and Organizational Commitment of University Teachers in Public Sector of Pakistan. International Journal of Business and Management, 5(6). https://doi.org/10.5539/ijbm.v5n6p17

Malone, P. N., \& Fry, L. W. (2003). Transforming Schools through Spiritual Leadership: A Field Experiment. Retrieved from https://www.iispiritualleadership.com/wpcontent/uploads/docs/SLTAOMPeggy0106.pdf

Mansor, N., \& Al., E. (2013). Ralationship between Spiritual Leadership and Organizational Commitment in Malaysians' and Gas Industry (7th ed., Vol. 9). Asian Social Science. https://doi.org/10.5539/ass.v9n7p179

Masouleh, S. A., Koochaksaraei, H. M., Saeedi, N., \& Mousavian, S. (2013). Studying the Relationship between Spiritual Leadership and Job Satisfaction. Human Resource 
Management. Retrieved from https://pdfs.semanticscholar.org/d7e1/c5114552c99cfb2705f33981eb218f07a0cc.pdf

Mayer, J. P., \& Allen, N. J. (2007). A Three-Component Conceptualization of Organizational Commitment: Some Methodological Considerations. Human Resource Management Review.

Milliman, J., \& E. (2018). The Effect of Workplace Spirituality on Hospitality Employee's Engagement, Intention to stay and service delivery (Vol. 35, Ser. 2018). Journal of Hospitality and Tourism. https://doi.org/10.1016/j.jhtm.2018.03.002

Misbah, H., Nadeem, A., \& Akhter, A. (2016). Impact of Workplace Spirituality on Job satisfaction: Mediating Effect of Trust (1st ed., Vol. 3, Ser. 2016). Cogent Business and Management. https://doi.org/10.1080/23311975.2016.1189808

Mora, T., \& Carbonell, A. (2009). The job satisfaction gender gap among recent university graduates: Evidence from Catalonia. Journal of Socio-Economics. https://doi.org/10.1016/j.socec.2009.02.003

Musta'in, M., Sanusi, A., \& Manan, A. (2014). A Study on Employees Performance: Spiritual Leadership and Work Motivation with Mediation Work Satisfaction at the University of Darul Ulum, Indonesia. European Journal of Business and Management,6(39), 2014th ser. Retrieved from https://www.iiste.org/Journals/index.php/EJBM/article/view/18823.

Nadeem, M. (2010). A study on job satisfaction factors of faculty members at the University of Balochistab. Serbian Journal of Management.

Northouse, P. G. (2016). Leadership: Theory and Practice. California: Sage Publication.

Osboei, F. K., \& Nojabaee, S. S. (2016). The relationship between spiritual leadership and quality of work life among employees: Case study of education offices in Mazandaran, Iran. International Journal of Humanities and Cultural Studies, 3(1), 2016th ser. Retrieved from http://www.ijhcs.com/index.php/ijhcs/article/view/1938

Panes, R. T., Gempes, G. P., \& Genuba, R. L. (2017). A causal model on job satisfaction among the teachers force of selected private schools in Region XI. International Journal of Scientific and Technology Research, 6(9), 2017th ser. Retrieved from http://www.ijstr.org/final-print/sep2017/A-Causal-Model-On-Job-Satisfaction-Among$\underline{\text { The-Teaching-Force-Of-Selected-Private-Schools-In-Region-Xi.pdf }}$ 
Pio, R. J., \& Tampi, J. R. (2018). The influence of spiritual leadership on quality of work life, job satisfaction and organizational citizenship behavior. International Journal of Law and Management, 60(2), 757-767. https://doi.org/10.1108/IJLMA-03-2017-0028

Reave, L. (2005). Spiritual values and practices related to leadership effectiveness. The Leadership Quarterly, 16(5), 655-687. https://doi.org/10.1016/j.leaqua.2005.07.003

Saari, L. M., \& Judge, T. A. (2004). Employee attitudes and job satisfaction. Human Resource Management, 43(4), 395-407. https://doi.org/10.1002/hrm.20032

Sharma, M., \& Hussain, A. (2012). Workplace spirituality and engagement among employees in public and private sector organisations. International Journal of Social and Allied Research.

Ssesanga, K., \& Garrett, R. M. (2005). Job satisfaction of University academics: Perspectives from Uganda. Higher Education, 50(1), 33-56. https://doi.org/10.1007/s10734-004-6346-0

Swanepoel, H. (2015). The relationship between workplace spirituality and work related attitudes.

Syed, A. A., Bhatti, N., Michael, S., Shaikh, F. M., \& Shah, H. (2012). Job Satisfaction of Faculty Members of Universities in Pakistan: A Case Study of University of SindhJamshoro. Modern Applied Science, 6(7). https://doi.org/10.5539/mas.v6n7p89

Walt, F. V. (2018). Workplace spirituality, work engagement and thriving at work. SA Journal of Industrial Psychology,44. https://doi.org/10.4102/sajip.v44i0.1457

Wubuli, A. (2009). A Study on the Factors Affecting Job Satisfaction amongst Employees of Fast Food Restaurants. Retrieved from http://etd.uum.edu.my/1836/2/1.Abuduaini_Wubuli.pdf

Yaghoubi, N., Moloudi, J., \& Banihashemi, S. (2010). The Relationship between Spirituality Leadership and Empowerment: A Case Study. American Journal of Scientific Research,X(12), 2010th ser. Retrieved from https://www.researchgate.net/publication/308748345_The_Relationship_between_Spirit uality_Leadership_and_Empowerment_A_Case_Study

Yusof, J. M. (2011). Spiritual Leadership and Job Satisfaction: A Proposed Conceptual Framework. Information Management and Business Review, 2(6), 2011th ser. Retrieved from https://ifrnd.org/journal/index.php/imbr/article/view/903 